\title{
Pelvis Cancer pT3a TNM Finding v8
}

National Cancer Institute

\section{Source}

National Cancer Institute. Pelvis Cancer pT3a TNM Finding v8. NCI Thesaurus. Code

C136601.

Pelvis cancer with tumor spanning two pelvic segments with extraosseous extension and measuring $8 \mathrm{~cm}$ or less in greatest dimension. (from AJCC 8th Ed.) 